University of South Florida

DIGITAL COMMONS

Digital Commons @ University of

@ UNIVERSITY OF SOUTH FLORIDA

South Florida

4-9-1998

\title{
Midwater Fishes and Shrimps as Competitors and Resource Partitioning in Low Latitude Oligotrophic Ecosystems
}

Thomas L. Hopkins

University of South Florida, thopkin1@tampabay.rr.com

Tracey T. Sutton

University of South Florida

Follow this and additional works at: https://digitalcommons.usf.edu/msc_facpub

Part of the Marine Biology Commons

\section{Scholar Commons Citation}

Hopkins, Thomas L. and Sutton, Tracey T., "Midwater Fishes and Shrimps as Competitors and Resource Partitioning in Low Latitude Oligotrophic Ecosystems" (1998). Marine Science Faculty Publications. 33.

https://digitalcommons.usf.edu/msc_facpub/33

This Article is brought to you for free and open access by the College of Marine Science at Digital Commons @ University of South Florida. It has been accepted for inclusion in Marine Science Faculty Publications by an authorized administrator of Digital Commons @ University of South Florida. For more information, please contact digitalcommons@usf.edu. 


\title{
Midwater fishes and shrimps as competitors and resource partitioning in low latitude oligotrophic ecosystems
}

\author{
Thomas L. Hopkins, Tracey T. Sutton* \\ Department of Marine Science, University of South Florida, St. Petersburg, Florida 33701, USA
}

\begin{abstract}
Oligotrophic tropical-subtropical oceanic regimes constitute the largest and most ancient ecosystern on earth, with these enormous areas being characterized by high faunal diversity. The stability and age of the ecosystem have enabled the evolution of many similar species niches where there is considerable overlap in niche parameters such as food and space, resulting in high species packing, especially in the epi- and mesopelagic zones. Competition for limited resources undoubtedly exists and has been described by MacArthur (1972; Geographical ecology, Harper and Row, New York) as diffuse competition where each species is impacted by many other species sharing the environment. Most studies of resource partitioning in the oceanic pelagial have been restricted to specific taxonomic groups, such as copepods, fishes, shrimps, or cephalopods, and intergroup relationships have not been examined. The 2 dominant (numbers and biomass) components of low latitude midwater micronekton communities, based on trawl catches, are fishes and shrimps, and the present study reveals that species from each of these 2 assemblages occur in the same feeding guilds and hence potentially compete for food resources. However, as additional niche parameters are included in the analysis, such as food size and predator vertical distribution, groups of species with matching niche characteristics become increasingly smaller. Results of this study suggest that as additional information on individual life histories is obtained, such as data on seasonality of reproduction and population dynamics, the same pattern will emerge as we have found for fishes and shrimps considered separately, i.e. that resource partitioning occurs at the species level despite the pressures of diffuse intra- and intergroup competition. This minimizes competitive exclusion and enables the maintenance of a high-diversity fauna in resource-poor low latitude ecosystems.
\end{abstract}

KEY WORDS: Gulf of Mexico - Oceanic ecosystem - Decapods - Myctophids - Food web - Vertical distribution

\section{INTRODUCTION}

Of enduring interest to pelagic oceanic ecologists is the phenomenon of high faunal diversity in low latitude oligotrophic oceans (e.g. Hutchinson 1959, 1961). This occurs in a seemingly low stucture environment, with light, temperature and pressure demonstrating the only major physical changes with depth. For example, the micronekton assemblage in the eastern Gulf of Mexico (EGOM) is comprised of over 200 species of midwater fishes, over 50 species of decapod and mysid

Addressee for correspondence.

E-mail: sutton@marine.usf.edu shrimps and approximately 60 species of cephalopods and large heteropods in the upper $1000 \mathrm{~m}$, with most occurring in the upper 200 to $300 \mathrm{~m}$ at night. Many of these species share the same vertical zones and food resources, and the obvious question is how diversity is maintained with a presumed minimum loss of species from the system due to competitive exclusion. MacArthur (1972, see also Pianka 1974) suggested that individual species in complex ecosystems are impacted by many other species, the results being cumulative 'diffuse competition'. Most studies addressing resource partitioning in the midwater pelagial have been limited to discrete taxonomic groups such as fishes (Clarke 1978, Domanski 1984, Hopkins \& Gartner 
1992), shrimps (Donaldson 1975, Walters 1976, Heffernan \& Hopkins 1981, Flock \& Hopkins 1992, Hopkins et al. 1994) or cephalopods (Passarella \& Hopkins 1991), whereas diffuse competition may include species from widely disparate taxonomic groups which competitively interact. Previous studies (e.g. Maynard et al. 1975, Hopkins \& Lancraft 1984) have shown that the 2 dominant components of low latitude micronekton communities are shrimps and fishes, and that these 2 components show spatial concurrence and dietary similarities. In this paper, we examine aspects of diet and vertical distribution of the midwater fishes and shrimps in the EGOM, a low latitude oligotrophic environment, and apply cluster analyses to assess the amount of niche overlap in these 2 groups. Our objective is to enable further insight in the phenomenon of rich faunal diversity in the low latitude pelagial.

\section{MATERIALS AND METHODS}

Information on midwater fish and shrimp assemblage structure has been accumulated over a 20 yr sampling period ( 25 cruises) at $27^{\circ} \mathrm{N} 86^{\circ} \mathrm{W}$, a station of $3200 \mathrm{~m}$ depth in the EGOM. The various types of opening-closing midwater trawls used, including a MOCNESS (Wiebe et al. 1976), are described in Hopkins et al. (1973), Hopkins \& Baird (1975), Gartner et al. (1987) and Hopkins et al. (1996). Our sampling (1155 discrete trawl samples) has enabled us to resolve vertical distributions in the upper $1000 \mathrm{~m}$ to contiguous $25 \mathrm{~m}$ depth intervals. Diet information used in this study was from 4991 fish specimens from 26 species (range per species: 40 to 450 ; mean number per species: 192) and 1070 shrimp specimens from 21 species (range: 10 to 155 ; mean: 51). Fish and shrimp gut contents were examined microscopically in water or fuchsin-acid-stained glycerin. Contents were identified to the lowest possible taxonomic level and food measurements (to the nearest $0.1 \mathrm{~mm}$ ) were converted to estimates of dry organic weight of undigested prey using procedures described in Hopkins \& Gartner (1992), Hopkins et al. (1994, 1996), and Sutton \& Hopkins (1996a).

A principal consideration in the present analysis is post-capture feeding in trawl net cod ends. As stated in Hopkins et al. (1996), and others (Clarke 1978, 1980, Roe \& Badcock 1984), net feeding appears to be a minor source of bias because (1) it is usually readily recognized as such when it occurs, (2) gut fullness shows diel periodicity even though prey is always abundant in the cod end, (3) consistent differences are observed in diets of species occurring in the same trawl catches, (4) most micronektonic fishes and shrimps were small, fragile and arrived on deck to some degree damaged or moribund, and (5) stomach and intestinal contents (the latter presumably with a pre-trawl catch residence time) were similar.

Species in the present investigation were compared for each of 3 niche parameters, diet composition $(\%$ of food biomass of each of 15 prey categories: copepod, ostracod, amphipod, euphausiid, decapod, larvacean, salp, siphonophore, unidentified gelatinous tunic, polychaete, gastropod, cephalopod, chaetognath, fish, and other food), prey size (\% of food biomass in each of 13 size categories: $<1.0,1-1.9,2-2.9,3-3.9,4-4.9$, $5-5.9,6-6.9,7-7.9,8-8.9,9-9.9,10-14.9,15-19.9$, $>20 \mathrm{~mm}$ ) and species nighttime vertical distribution (\% of species population numbers in each $25 \mathrm{~m}$ zone from the surface to a depth of $1000 \mathrm{~m}$ ). For each niche parameter, Bray-Curtis (1957) dissimilarity indices were calculated for all combinations of cluster unit pairs, then these indices were subjected to hierarchical unweighted pair-group method using arithmetic averages (UPGMA) cluster analysis (Romesburg 1990) to determine taxonomic groupings for each of the 3 parameters. Clusters were defined at the $40 \%$ dissimilarity level as in previous studies (Zaret \& Rand 1971, Berkes 1976, Hopkins \& Gartner 1992).

The comparisons involved many more cluster units of fishes than shrimps ( 77 vs 21 units), this being a result of diet changes with ontogeny in fishes [detected by previous cluster analyses (see Hopkins et al. 1996)]. Many fish species were considered by size class, and numerical designations after fish species names (see Table 1) represent size class in $10 \mathrm{~mm}$ intervals of standard length (SL) (for example, 2: 20-29 mm SL, 3: $30-39 \mathrm{~mm} \mathrm{SL}$, and pairs of numbers separated by a slash, e.g. 10/19, represent pooled data for several size classes, in this case 100-199 mm SL). Pooling was applied to very large fish species [e.g. Gonostoma elongatum, the Stomiidae (sensu Fink 1985)] which have a large size range. Changes in diet with ontogeny in shrimps are highly probable, but were not detectable through cluster analysis (Hopkins et al. 1994). This contrast in ontogenetic diet patterns for fishes and shrimps in part results from differences in the way prey is manipulated in these 2 groups -fish swallow prey whole, so prey size is limited by mouth size, whereas shrimps masticate their food.

Data from the 3 cluster analyses were combined in a trellis matrix (e.g see Fig. 7 in Hopkins et al. 1994) which compared all combinations of cluster unit pairs. The matrix grid was tallied square by square for cluster unit pairs which demonstrated no niche separation, or niche separation by a single parameter, by 2 parameters, or by all 3 parameters. The term 'cluster unit' is used rather than 'species' in describing cluster and trellis matrix composition because in the case of fishes more than 1 size class could occur in a single cluster and/or in several different clusters. The trellis matrix 
and parameter cluster analyses are summarized in tables rather than included in the paper because of their large dimensions in relation to journal page size.

\section{RESULTS}

\section{Prey item composition}

The species treated in cluster analyses are listed in Table 1. These species combined represent 90 and $99 \%$, respectively, of the numbers of fishes and shrimps in the upper $1000 \mathrm{~m}$ of the EGOM. The cluster analysis summary for diet composition (Table 2), based on 20183 and 3302 prey items of fish and shrimp, respectively, revealed 2 large clusters (Clusters 1 and 2), 2 of intermediate size (Clusters 11 and 14) with most of the remainder (14 clusters) containing only 1 to 4 cluster units. All 4 of the large- and intermediate-sized clusters included both fishes and shrimps.

Cluster 1, the largest (29 cluster units), combined predators which fed almost entirely on small crustaceans (food biomass range: 80 to $100 \%$; mean: $97 \%$ ), with copepods the overwhelmingly dominant prey (range: 67 to $99 \%$; mean: $86 \%$ ). The potential for competition between fishes and shrimps for the same resource is apparent in Table 3 , which lists the principal copepod genera in the diets of myctophids and sergestids, 2 of the dominant families in the fish and shrimp assemblages, respectively. Eleven of the 15 (including 4 of the top 5) copepod prey genera appeared in both lists. It should be noted that 89 and $81 \%$ of the copepods encountered in the digestive tracts of myctophids and sergestids, respectively, were identified at least to genus. Hence, any bias due to unidentified copepods was small. At the head of each list is the copepod genus Pleuromamma (of which there are 4 abundant species in the EGOM), with $P$. abdominalis and $P$. xiphias contributing the most biomass to the diets of both myctophids and sergestids. Cluster 2, with 21 cluster units, aggregated fishes and shrimps which fed on small crustaceans (range: 66 to $100 \%$; mean: $87 \%$ ) including copepods, ostracods and amphipods, along with small euphausiids and decapods. Copepods were again the principal food biomass (range: 29 to $57 \%$; mean: $45 \%$ ), but contributed proportionately less to diets than in Cluster 1.
Cluster 11, with 10 cluster units, was another mixed group of fishes and shrimps which fed primarily on crustaceans (range: 76 to $99 \%$; mean: $88 \%$ ), but with larger prey such as euphausiids playing a more important role in diets (range: 40 to $79 \%$; mean: $59 \%$ ). Fishes occurred in the diet of some of these predators as well (maximum 25\% in the diet of Gonostoma elongatum $5 / 7$ ). Cluster 14 , mostly a shrimp cohort ( 8 of 9 species), was characterized by a mixed diet of both crustacean (range: 26 to $55 \%$; mean: $42 \%$ ) and non-crustacean (range: 45 to $73 \%$; mean: $58 \%$ ) food, with larger elongate prey such as chaetognaths (mean: $14 \%$ ), euphausiids (mean: $26 \%$ ) and fishes (mean: $34 \%$ ) contributing the most to food biomass.

It is apparent from Table 2 that different size classes of many fish species (e.g. Gonostoma elongatum, Ceratoscopelus warmingii, Argyropelecus aculeatus, Sternoptyx diaphana, S. pseudobscura) fall into different clusters. This primarily resulted from changes in diet composition with ontogeny. Also, what appears to be marine snow was prominent in the stomachs of certain shrimps, e.g. the 4 aristeid Gennadas spp. and 
Table 2. Cluster analysis summary of diet composition (\% of food biomass of each prey type) of the fish and shrimp assemblages in the upper $1000 \mathrm{~m}$ of the eastern Gulf of Mexico. Cluster units listed in the sequence they occurred in each cluster. Numbers after species names indicate size class

\begin{tabular}{|c|c|}
\hline Cluster 1 & $\begin{array}{l}\text { Cyclothone acclinidens-2, Cyclothone acclinidens-3, Cyclothone braueri-2, Cyclothone pseudopallida-3, } \\
\text { Sergestes pectinatus, Cyclothone pseudopallida-1, Cyclothone pseudopallida-2, Cyclothone alba-1, Notoly- } \\
\text { chnus valdiviae-1, Cyclothone braueri-1, Cyclothone alba-2, Valenciennellus tripunctulatus-3, Valencien- } \\
\text { nellus tripunctulatus-1, Valenciennellus tripunctulatus-2, Eucopia sculpticauda, Eucopia australis, Mycto- } \\
\text { phum affine-2, Myctophum affine-3, Lampanyctus alatus-1, Notolychnus valdiviae-2, Sergestes sargassi, } \\
\text { Notoscopelus resplendens-2, Lepidophanes guentheri-1, Benthosema suborbitale-1, Benthosema subor- } \\
\text { bitale-2, Lampanyctus alatus-2, Myctophum affine-1, Eucopia unguiculata, Diaphus mollis-4 }\end{array}$ \\
\hline Cluster 2 & $\begin{array}{l}\text { Lampanyctus alatus-3, Notoscopelus resplendens-5, Lampanyctus alatus-4, Lepidophanes guentheri-2, } \\
\text { Lepidophanes guentheri-5, Lepidophanes guentheri-6, Lepidophanes guentheri-3, Sergestes atlanticus, } \\
\text { Sergestes paraseminudus, Cyclothone pallida-2/3, Vinciguerria poweriae-1, Ceratoscopelus warmingii-1, } \\
\text { Sternoptyx pseudobscura-2, Notoscopelus resplendens-3, Notoscopelus resplendens-4, Gonostoma elonga- } \\
\text { tum-1/2, Gonostoma elongatum-3/4, Diaphus dumerilii-1, Diaphus dumerili-2, Cyclothone acclinidens- } 1 \text {, } \\
\text { Cyclothone pallida-4 }\end{array}$ \\
\hline Cluster 3 & Diaphus mollis-2, Diaphus mollis-3, Diaphus dumerilii-3, Sergia robustus, Sergia splendens \\
\hline Cluster 4 & Sternoptyx pseudobscura-1 \\
\hline Cluster 5 & Sternoptyx pseudobscura-3 \\
\hline Cluster 6 & Argyropelecus aculeatus-1, Argyropelecus hemigymnus-1, Argyropelecus hemigymnus-2 \\
\hline Cluster 7 & Ceratoscopelus warmingii-2, Ceratoscopelus warmingii-3 \\
\hline Cluster 8 & Ceratoscopelus warmingii-4 \\
\hline Cluster 9 & Sternoptyx diaphana-2, Sternoptyx diaphana-3 \\
\hline Cluster 10 & Sternoptyx diaphana-1 \\
\hline Cluster 11 & $\begin{array}{l}\text { Gonostona elongatum-5/7, Vinciguerria poweriae-2, Vinciguerria poweriae-3, Gonostoma elongatum-8/9, } \\
\text { Gonostoma elongatum-10/1.2, Sergestes armatus, Sergestes vigilax, Sergestes edwardsii, Lepidophanes } \\
\text { guentheri-4, Sergestes henseni }\end{array}$ \\
\hline Cluster 12 & Diaphus lucidus-5, Diaphus lucidus-6, Diaphus lucidus-4 \\
\hline Cluster 13 & Argyropelecus aculeatus-2, Argyropelecus aculeatus-3 \\
\hline Cluster 14 & $\begin{array}{l}\text { Gennadas bouvieri, Gennadas capensis, Gennadas valens, Gennadas scutatus, Vinciguerria nimbaria-3, } \\
\text { Acanthephyra purpurea, Systellaspis debilis, Acanthephyra curtirostris, Parapandalus richardi }\end{array}$ \\
\hline Cluster 15 & Chauliodus sloani-2/20, Stomias affinis-2/19, Sternoptyx pseudobscura-4/5 \\
\hline Cluster 16 & Vinciguerria nimbaria-1, Vinciguerria nimbaria-2 \\
\hline Cluster 17 & Argyropelecus aculeatus-4/5 \\
\hline Cluster 18 & Diaphus lucidus-3, Photostomias guernei-3/12 \\
\hline
\end{tabular}

Table 3. Comparison of copepod composition (\% biomass of copepods identified to genus) in diets of the Myctophidae and Sergestidae of the eastern Gulf of Mexico

\begin{tabular}{|lrlr|}
\hline \multicolumn{3}{|c}{ Myctophidae } & \multicolumn{2}{c|}{ Sergestidae } \\
Prey genus & \% diet & Prey genus & \% diet \\
\hline Pleuromamma & 48.3 & Pleuromamma & 39.9 \\
Euchaeta & 12.3 & Euchaeta & 22.2 \\
Undeuchaeta & 8.2 & Candacla & 21.3 \\
Undinula & 5.4 & Undinula & 4.7 \\
Candacia & 4.5 & Chirundina & 2.6 \\
Scolecithrix & 4.5 & Euchirella & 2.4 \\
Nannocalanus & 2.9 & Eucalanus & 2.2 \\
Corycaeus & 2.9 & Scottocalanus & 1.1 \\
Temora & 2.0 & Nannocalanus & 0.8 \\
Neocalanus & 1.9 & Rhincalanus & 0.7 \\
Eucalanus & 1.5 & Corycaeus & 0.7 \\
Rhincalanus & 0.9 & Oncaea & 0.6 \\
Paracandacia & 0.8 & Paracandacia & 0.4 \\
Euchirella & 0.7 & Gaetanus & 0.3 \\
Scottocalanus & 0.7 & Phyllopus & 0.1 \\
Other genera (8) & 2.5 & Other genera (1) & $<0.1$ \\
& & & \\
\hline
\end{tabular}

the 2 Sergia spp. This material often constituted most of the food volume but was not successfully quantified by our methods in terms of biomass; these 2 shrimp genera perhaps belong in 1 or possibly 2 separate clusters.

\section{Prey size}

Cluster analysis of data on food size (Table 4) yielded 11 clusters, with 3 of these (Clusters 1, 5 and 7) containing 10 or more cluster units. Cluster 1, the largest, with 45 units, grouped species which fed mostly on relatively small prey $(<6 \mathrm{~mm})$. The percent range for this size fraction was 43 to $100 \%$ of food biomass, with an average of $70 \%$. The species composition of this dominant cluster closely aligned ( 37 of 45 cluster units) with those in the large clusters ( 1 and 2 ) of the diet composition analysis (Table 2), where small- to intermediatesized crustaceans were the principal food and copepods were the largest biomass category. Cluster 1 
Table 4. Cluster analysis summary of size composition (\% food biomass in each size category) of diets of Gulf of Mexico midwater fishes and shrimps. Listings are in order of occurrence in each cluster

\begin{tabular}{|c|c|}
\hline Cluster 1 & $\begin{array}{l}\text { Cyclothone acclinidens-1, Cyclothone acclinidens-2, Argyropelecus hemigymnus-2, Cyclothone alba-2, } \\
\text { Cyclothone pseudopallida-3, Valenciennellus tripunctulatus-3, Cyclothone braueri-2, Notolychnus val- } \\
\text { diviae-2, Cyclothone acclinidens-3, Notolychnus valdiviae-1, Sergestes sargassi, Cyclothone pseudopallida- } \\
\text { 1, Cyclothone pseudopallida-2, Cyclothone alba-1, Valenciennellus tripunctulatus-2, Cyclothone braueri-1, } \\
\text { Sergestes pectinatus, Eucopia unguiculata, Sternoptyx pseudobscura-1, Myctophum affine-2, Valencien- } \\
\text { nellus tripunctulatus-1, Lampanyctus alatus-1, Myctophum affine-3, Benthosema suborbitale-1, Lampanyc- } \\
\text { tus alatus-2, Benthosema suborbitale-2, Gonostoma elongatum-3/4, Notoscopelus resplendens- } 2 \text {, Lepido- } \\
\text { phanes guentheri-1, Gonostoma elongatum-1/2, Ceratoscopelus warmingii-3, Diaphus mollis-4, } \\
\text { Ceratoscopelus warmingii-2, Lepidophanes guentheri-2, Eucopia sculpticauda, Ceratoscopelus warmingii- } \\
\text { 1, Vinciguerria poweriae-1, Diaphus dumerili-3, Diaphus mollis-2, Cyclothone pallida-2/3, Diaphus dumer- } \\
\text { ili-2, Argyropelecus aculeatus-1, Argyropelecus hemigymnus-1, Diaphus dumerilii-1, Myctophum affine-1 }\end{array}$ \\
\hline Cluster 2 & $\begin{array}{l}\text { Sergestes paraseminudus, Sergia robustus, Sergia splendens, Sergestes atlanticus, Sergestes henseni, } \\
\text { Sternoptyx pseudobscura-2 }\end{array}$ \\
\hline Cluster 3 & Vinciguerria nimbaria-2 \\
\hline Cluster 4 & Eucopia australis \\
\hline Cluster 5 & $\begin{array}{l}\text { Diaphus lucidus-4, Sternoptyx diaphana-3, Lampanyctus alatus-4, Notoscopelus resplendens-5, Lepido- } \\
\text { phanes guentheri-4, Argyropelecus aculeatus-2, Lepidophanes guentheri-3, Lepidophanes guentheri-6, } \\
\text { Lampanyctus alatus-3, Ceratoscopelus warmingii-4, Notoscopelus resplendens-4, Sternoptyx diaphana-1, } \\
\text { Sternoptyx diaphana-2, Lepidophanes guentheri-5, Diaphus mollis-3, Notoscopelus resplendens-3, Argyro- } \\
\text { pelecus aculeatus-3 }\end{array}$ \\
\hline Cluster 6 & Gonostoma elongatum-5/7, Parapandalus richardi \\
\hline Cluster 7 & $\begin{array}{l}\text { Acanthephyra curtirostris, Systellaspis debilis, Gennadas scutatus, Gennadas valens, Vinciguerria powe- } \\
\text { riae-2, Gennadas bouvieri, Gennadas capensis, Diaphus lucidus-6, Sergestes vigilax, Vinciguerria nim- } \\
\text { baria-3, Vinciguerria poweriae-3, Sergestes armatus }\end{array}$ \\
\hline Cluster 8 & Cyclothone pallida-4 \\
\hline Cluster 9 & $\begin{array}{l}\text { Diaphus lucidus-5, Argyropelecus aculeatus-4/5, Gonostoma elongatum-8/9, Gonostoma elongatum-10/12, } \\
\text { Sternoptyx pseudobscura-3, Acanthephyra purpurea }\end{array}$ \\
\hline Cluster 10 & $\begin{array}{l}\text { Sternoptyx pseudobscura-4/5, Photostomias guernei-3/12, Chauliodus sloani-2/20, Diaphus Iucidus-3, Sto- } \\
\text { mias affinis- } 2 / 19\end{array}$ \\
\hline Cluster 11 & Vinciguerria nimbaria-1, Sergestes edwardsii \\
\hline
\end{tabular}

included both fishes and shrimps. Cluster 5, grouping 17 cluster units (all fishes), had members which also fed on small- to intermediate-sized prey, but most prey were smaller than $6 \mathrm{~mm}$ (range: 32 to $64 \%$; mean: $53 \%$ ). The composition of this cluster showed similarities ( 8 of 17 species concurrent) with diet composition Cluster 2. The third largest group, Cluster 7 , was composed of 8 shrimp and 4 fish cluster units which fed on relatively large prey, most of which exceeded $10 \mathrm{~mm}$ (range: 41 to $74 \%$; mean: $60 \%$ ). Species composition was similar to that of diet composition Cluster 14 in which chaetognaths, euphausiids and fish averaged $74 \%$ of food biomass. Cluster 2 contained 6 cluster units, 1 fish (Sternoptyx pseudobscura) and 5 sergestid shrimp units, with food biomass approximately evenly split between less than $6 \mathrm{~mm}$ (mean: $54 \%$ ) and greater than $6 \mathrm{~mm}$ (mean: $46 \%$ ) prey. Cluster 9 also grouped 6 cluster units, including 1 shrimp, Acanthephyra purpurea. Most of the food biomass of members of this cluster exceeded $10 \mathrm{~mm}$ in size (range: 63 to $75 \%$; mean: $67 \%$ ) and consisted of chaetognaths, fish, euphausiids, and large pteropods and polychaetes. Cluster 10 aggregated 5 fish cluster units, 3 of which were the most abundant stomiid species in the EGOM,
Photostomias guernei, Chauliodus sloani and Stomias affinis (Sutton \& Hopkins 1996b). Food biomass was mostly in the $>10 \mathrm{~mm}$ size category (range: 72 to $99 \%$; mean: $88 \%$ ), with prey consisting primarily of large decapods and fishes. The remaining 5 clusters $(3,4,6$, 8 and 11) were comprised of 1 or 2 species each, and in 6 of 7 cases the major size fraction of food biomass was larger than $6 \mathrm{~mm}$.

\section{Spatial distribution}

Cluster analysis of nighttime vertical distribution (Table 5) yielded the largest number of clusters, 26, of any of the 3 niche variables, with the species composition of these clusters having little apparent correlation with food type or size. Only 4 clusters contained 10 or more cluster units (Clusters 2, 4, 7 and 15). Cluster 2, the largest, had 18 cluster units, all fishes except for Parapandalus richardi. Fourteen of the 18 units had population centers (i.e. where half the population resides above and below a depth zone) in the middle of the epipelagic zone at 75 to $125 \mathrm{~m}$, the median zone being 75 to $100 \mathrm{~m}$. Cluster 4 had 11 cluster units which 
Table 5. Cluster analysis summary of nighttime vertical distributions of midwater fishes and shrimps in the upper $1000 \mathrm{~m}$ of the eastern Gulf. Cluster units in sequence they occurred in each cluster

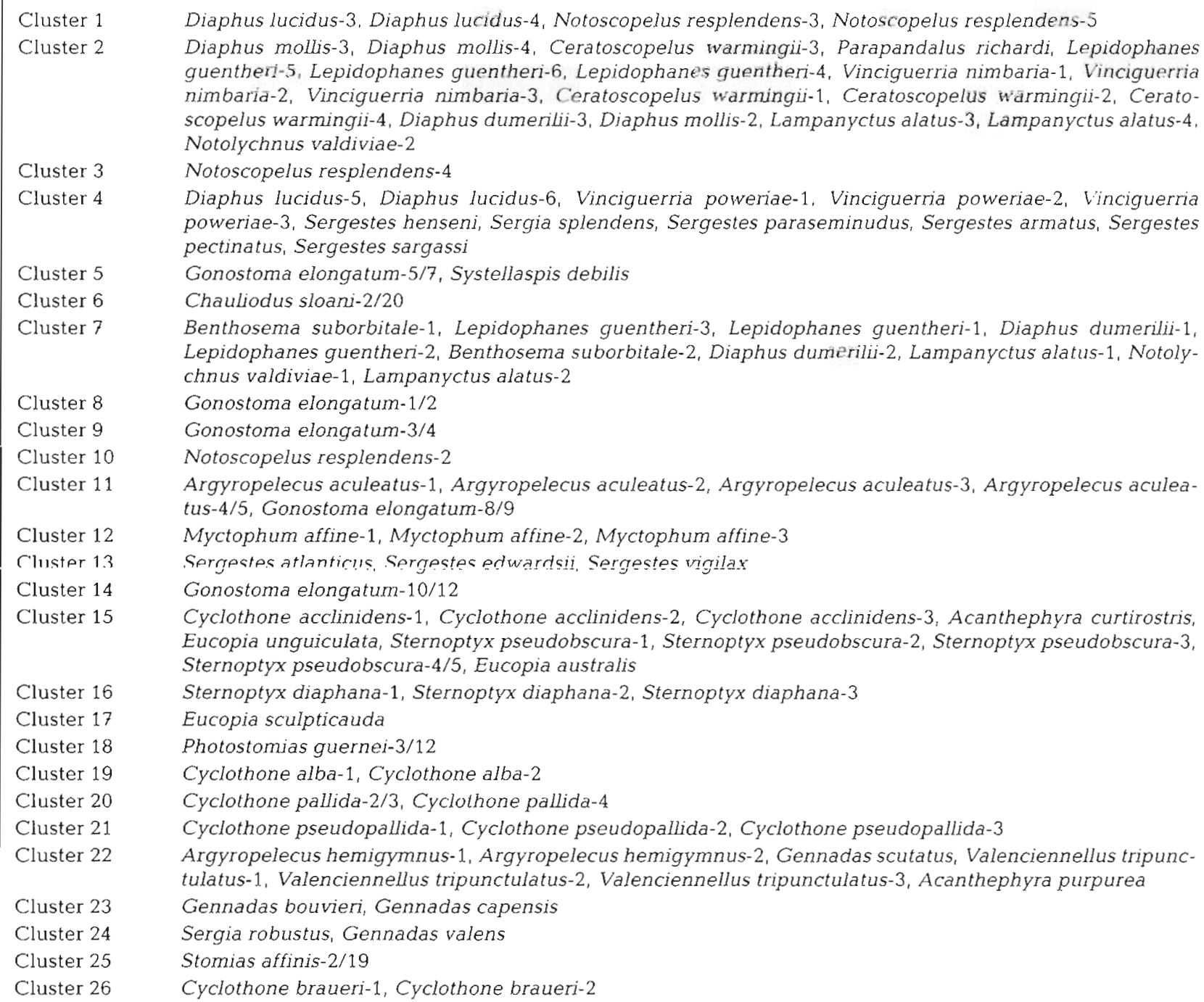

Cluster 4 Diaphus Iucidus-5, Diaphus lucidus-6, Vinciguerria poweriae-1, Vinciguerria poweriae-2, Vinciguerria poweriae-3, Sergestes henseni, Sergia splendens, Sergestes paraseminudus, Sergestes armatus, Sergestes pectinatus, Sergestes sargassi

Cluster $5 \quad$ Gonostoma elongatum-5/7, Systellaspis debilis

Cluster $6 \quad$ Chauliodus sloani-2/20

Cluster 7 Benthosema suborbitale-1, Lepidophanes guentheri-3, Lepidophanes guentheri-1, Diaphus dumerilii-1, Lepidophanes guentheri-2, Benthosema suborbitale-2, Diaphus dumerilii-2, Lampanyctus alatus-1, Notolychnus valdiviae-1, Lampanyctus alatus-2

Cluster $8 \quad$ Gonostoma elongatum-1/2

Cluster $9 \quad$ Gonostoma elongatum-3/4

Cluster $10 \quad$ Notoscopelus resplendens-2

Cluster 11 Argyropelecus aculeatus-1, Argyropelecus aculeatus-2, Argyropelecus aculeatus-3, Argyropelecus aculeatus-4/5, Gonostoma elongatum-8/9

Cluster 12 Myctophum affine-1, Myctophum affine-2, Myctophum affine-3

Cluster 1.3 Sergestes atlanticus Sergestes edwardsii, Sergestes vigilax

Cluster 14 Gonostoma elongatum-10/12

Cluster 15 Cyclothone acclinidens-1, Cyclothone acclinidens-2, Cyclothone acclinidens-3, Acanthephyra curtirostris, Eucopia unguiculata, Sternoptyx pseudobscura-1, Sternoptyx pseudobscura-2, Sternoptyx pseudobscura-3, Sternoptyx pseudobscura-4/5, Eucopia australis

Cluster 16 Sternoptyx diaphana-1, Sternoptyx diaphana-2, Sternoptyx diaphana-3

Cluster 17 Eucopia sculpticauda

Cluster 18 Photostomias guernei-3/12

Cluster 19 Cyclothone alba-1, Cyclothone alba-2

Cluster $20 \quad$ Cyclothone pallida-2/3, Cyclothone pallida-4

Cluster 21 Cyclothone pseudopallida-1, Cyclothone pseudopallida-2, Cyclothone pseudopallida-3

Cluster 22 Argyropelecus hemigymnus-1, Argyropelecus hemigymnus-2, Gennadas scutatus, Valenciennellus tripunctulatus-1, Valenciennellus tripunctulatus-2, Valenciennellus tripunctulatus-3, Acanthephyra purpurea

Cluster 23

Cluster 24

Cluster 25

Gennadas bouvieri, Gennadas capensis

Sergia robustus, Gennadas valens

Stomias affinis-2/19

Cluster 26 Cyclothone braueri-1, Cyclothone braueri-2

included several size classes each of the myctophid Diaphus lucidus, the phosichthyid Vinciguerria poweriae, and 6 species of sergestids. All of these units were centered in the lower half of the epipelagic zone at 125 to $175 \mathrm{~m}$ (median zone 125 to $150 \mathrm{~m}$ ). Cluster 7 grouped 10 cluster units of myctophids which centered shallow in the epipelagic zone at 25 to $50 \mathrm{~m}$. Cluster 15, also of 10 units, had an array of non-migrators including representatives of the fish genera Cyclothone and Sternoptyx and the shrimp genera Eucopia and Acanthephyra. These occurred deep in the mesopelagic zone at night ( 825 to $925 \mathrm{~m}$; median zone 900 to $925 \mathrm{~m}$ ). Three clusters, 1,11 and 22 , had 4 to 7 units. Cluster 22, a mixture of sternoptychid fish and aristeid and caridean shrimp species, occurred in the upper mesopelagic zone, the median depth being
300 to $325 \mathrm{~m}$. Cluster 11 grouped 4 size classes of Argyropelecus aculeatus and one unit of Gonostoma elongatum, with their populations centering in the lower epipelagic zone at 150 to $175 \mathrm{~m}$. Cluster 1 contained several size classes each of 2 myctophids, Diaphus Iucidus and Notoscopelus resplendens, which also centered in the lower epipelagic zone, between 75 and $150 \mathrm{~m}$.

The remaining 19 clusters, each with 1 to 3 units, can be assigned to 3 broad depth zones: epipelagic (0 to $250 \mathrm{~m}$ ), upper mesopelagic (250 to $650 \mathrm{~m}$ ) and deep mesopelagic $(>650 \mathrm{~m})$. The shallow depth group included 9 clusters $(3,5,6,8,9,10,12,13$ and 14) consisting of strongly migrating myctophids, sergestids, stomiids and Gonostoma elongatum. The intermediate depth group had 7 clusters $(18,19,21,23,24,25$ and 
Table 6 . Results of multiple niche parameter cluster analyses for resource partitioning among the midwater fishes and shrimps of the eastern Gulf of Mexico. The 3 niche parameters considered were diet composition, food size and predator nighttime vertical distribution

\begin{tabular}{|lrr|}
\hline & Number of pairings & $\%$ of total pairings \\
\hline Species pair concurrences for all 3 parameters (i.e. no niche separation) & $48^{\mathrm{d}}$ & 1.0 \\
Species niche separation based on a single parameter & 531 & 11.2 \\
Niche separation based on 2 parameters & 31064 & 22.4 \\
Niche separation based on all 3 parameters & 4753 & 65.4 \\
Total pairings in analysis & \\
a23 of the concurrences were pairings of different size classes of the same species & \\
\hline
\end{tabular}

26) and included shallow Sergia and Gennadas shrimps, Cyclothone and the stomiids. This group had portions of or entire populations which did not migrate or, if migrating, did not reach the epipelagic zone at night. The deepest group (Clusters 16, 17 and 20) included deep mesopelagic Cyclothone and Sternoptyx and the mysid shrimp genus Eucopia.

It should be noted that defining depth centers for the Stomiidae was especially problematic as a significant fraction of their populations do not migrate on a daily basis but remain at depth, thereby generating a strongly polymodal vertical distribution pattern (Sutton \& Hopkins 1996b). Our feeding data, however, suggest that most stomiid predation is in the epipelagic zone at night, with little feeding occurring in the nonmigratory components of the populations (Sutton \& Hopkins 1996a). Also note that a number of species were distributed over more than 1 depth cluster, examples being Gonostoma elongatum and Notoscopelus resplendens, which occur, respectively, in 5 and 3 different clusters. This results from changes in species migration patterns which occur with ontogeny (e.g. Badcock 1970, Gibbs et al. 1971, Badcock \& Merrett 1976, Clarke 1978, Willis \& Pearcy 1980, Hulley 1981, Gartner et al. 1987, Lancraft et al. 1988), with larger, older individuals of a species more often found deeper in the water column.

\section{Trellis matrix results for species pairs}

Using the species pairs trellis diagram we were able to estimate the degree of niche overlap or, conversely, niche differentiation, with the 3 niche parameters combined. Trellis analysis yielded a total of 4753 combinations of cluster pairings of 77 fish and 21 shrimp units. The data summary in Table 6 shows that in only 48 cases (i.e. $1 \%$ of all pairings) was there no niche differentiation. Approximately half this number (23) were pairings of different size classes of the same fish species. The pairings involving different species included: combinations of 8 myctophid species; Cyclothone acclinidens and Eucopia unguiculata; Vinciguerria poweriae and Sergestes armatus; Sergestes pectinatus and Sergestes sargassi; and Gennadas capensis and Gennadas bouvieri. In 2 instances there was no apparent niche differentiation between a fish and a shrimp species (Eucopia unguiculata and Cyclothone acclinidens 2,3, Sergestes armatus and Vinciguerria poweriae 2,3 ). The remainder of the 4753 pairings yielded niche differentiation by a single parameter, 2 parameters or all 3 parameters. Thus, $99 \%$ of the pairings demonstrated some degree of niche separation. Only $11 \%$ of the pairings showed single parameter differentiation, whereas $88 \%$ were differentiated by 2 or more parameters, with $65 \%$ of all pairings being differentiated by all 3 niche variables.

\section{DISCUSSION}

The 3 variables considered as important niche parameters were food composition, food size and nighttime predator vertical distribution. Two of the parameters were based on nutrition and one on space. In the mesopelagic ecosystem, spatial separation or concurrence at night is a valid estimator of potential competition for vertically distributed resources as vertically migrating species generally feed at night (e.g. Omori 1969, Foxton \& Roe 1974, Merrett \& Roe 1974, Donaldson 1975, Hopkins \& Baird 1975, Walters 1976, Gorelova 1977. Kinzer \& Schulz 1985, Kawamura \& Fujii 1988). Animals feeding at different horizons, even on the same prey species, at night in the epi/mesopelagic zone are partitioning the common resource and thus minimizing competition. Our data suggest that diffuse competition exists as MacArthur (1972) and Pianka (1974) predicted and that species niches in the ecosystem show considerable overlap (e.g. consider the large multispecies clusters in Tables 2 \& 4). The latter enables dense species packing, especially in the epipelagic zone at night, the apparent period of most 
active feeding. Not all of the species considered here, however, forage exclusively at night. Hopkins \& Baird (1973) and Baird \& Hopkins (1981) have shown that there is active feeding during the daytime by the nonmigratory sternoptychids (Valenciennellus, Sternoptyx) and Lancraft (pers. comm.) has made similar observations on Cyclothone, and there is evidence that, while EGOM aristeids feed primarily at night, foraging continues throughout the diel period (Hefferran \& Hopkins 1981). Others have reported daytime or acyclic feeding in myctophids (Samyshev \& Shetinkin 1971, Clarke 1978), sternoptychids (Merrett \& Roe 1974, Clarke 1978), gonostomatids (DeWitt \& Cailliet 1972), and aristeid, sergestid, caridean and mysid shrimps (Roe 1984, Nishida et al. 1988). Spreading predation pressure over the $24 \mathrm{~h}$ diel period would enhance resource partitioning and not be in conflict with the concept of niche separation being discussed here.

In summary, our analysis supports the concept of diffuse competition, where individual species are impacted by many other species in the ecosystem, including intergroup competitive pressure. The present results have demonstrated much niche coherence between representatives of the 2 dominant micronektonic taxa, the midwater fishes and shrimps. Despite considerable niche overlap and thus the potential for competition, it appears that when a spectrum of niche parameters is considered, resource partitioning exists at the species level and in many instances, intraspecifically, at the size cohort level as well. This enables the high species diversity observed in warm water oligotrophic regimes which so characterizes the epi/ mesopelagic zone of a large fraction of the world ocean.

Acknowledgements. This research was funded by National Science Foundation contracts DES 75-03845 and OCE 84 10787. We thank Jodie Helle for manuscript preparation.

\section{LITERATURE CITED}

Badcock J (1970) The vertical distribution of mesopelagic fishes collected on the SOND cruise. J Mar Biol Assoc UK 50:1001-1044

Badcock J, Merrett NR (1976) Midwater fishes in the eastern North Atlantic-I. Vertical distribution and associated biology in $30^{\circ} \mathrm{N}, 23^{\circ} \mathrm{W}$, with developmental. notes on certain myctophids. Prog Oceanogr 7:3-58

Baird RC. Hopkins TL (1981) Trophodynamics of the fish Valencienellus tripunctulatus. II. Selectivity, grazing rates and resource utilization. Mar Ecol Prog Ser 5:11-19

Berkes F (1976) Ecology of euphausiids in the Gulf of St. Lawrence. J Fish Res Bd Can 33:1894-1905

Bray JR, Curtus JT (1957) An ordination of the upland forest communities of southern Wisconsin. Ecol Monogr 27: $325-349$

Clarke TA (1978) Diel feeding patterns of 16 species of mesopelagic fishes from Hawalian waters. Fish Bull US 76: $485-513$
Clarke TA (1980) Diets of fourteen species of vertically migrating mesopelagic fishes in Hawaian waters. Fish Bull US 78:619-640

DeWitt FA. Jr, Cailliet GM (1972) Feeding habits of two bristlemouth fishes, Cyclothone acclinidens and C. signata (Gonostomatidae). Copeia 1972:868-871

Domanski P (1984) Diel migrations and distributions within a mesopelagic community in the north east Atlantic. 8 . A multivariate analysis of community structure. Prog Oceanogr 13:491-511

Donaldson HA (1975) Vertical distribution and feeding of sergestid shrimps (Decapoda: Natantia) collected near Bermuda. Mar Biol 31:37-50

Fink WL (1985) Phylogenetic relationships of the stomiid fishes (Teleostei: Stomiiformes). Misc Publ Mus Zool Univ Mich 171:1-127

Flock ME, Hopkins TL (1992) Species composition, vertical distribution, and food habits of the sergestid shrimp assemblage in the eastern Gulf of Mexico. J Crust Biol 12 $210-223$

Foxton P, Roe HSJ (1974) Observations on the nocturnal feeding of some mesopelagic decapod Crustacea. Mar Biol 28 $37-49$

Gartner JV Jr, Hopkins TL, Baird RC, Milliken DM (1987) The lanternfishes (Pisces: Myctophidae) of the eastern Gulf of Mexico. Fish Bull US 85:81-98

Gibbs RH Jr, Goodyear RJ, Keene MJ, Brown DW (1971) Biological studies of the Bermuda Ocean Acre. II. Vertical distribution and ecology of the lanternfishes (family Myctophidae). Report to the US Navy Underwater Systems Center، p 1-141

Gorelova TA (1.977) Some characteristics of the nutration of the young of the nictoepipelagic and mesopelagic lantern fish (Pisces, Myctophidae). Oceanology 17:220-222

Heffernan JJ, Hopkins TL (1981) Vertical distribution and feeding of the shrimp genera Gennadas and Bentheogennema (Decapoda: Penaeidea) in the eastern Gulf of Mexico. J Crust Biol 1:461-473

Hopkins TL, Baird RC (1973) Diet of the hatchetfish Sternoptyx diaphana. Mar Biol 21:34-46

Hopkins TL, Baird RC (1975) Net feeding in mesopelagic fishes. Fish Bull US 73:908-914

Hopkins TL, Baird RC (1985) Feeding ecology of four hatchetfishes (Sternoptychidae) in the eastern Gulf of Mexico. Bull Mar Sci 36:260-277

Hopkins TL, Baird RC, Milliken DM (1973) A messengeroperated closing trawl. Limnol Oceanogr 18:488-490

Hopkins TL, Flock ME, Gartner JV Jr, Torres JJ (1994) Structure and trophic ecology of a low latitude midwater decapod and mysid assemblage. Mar Ecol Prog Ser 109:143-156

Hopkins TL, Gartner JV Jr (1992) Resource-partitioning and predation impact of a low-latitude myctophid community Mar Biol 1 1.4:185-197

Hopkins TL, Lancraft TM (1984) The composition and standing stock of mesopelagic micronekton at $27^{\circ} \mathrm{N} 86^{\circ} \mathrm{W}$ in the eastern Gulf of Mexico. Contrib Mar Sci 27:143-158

Hopkins TL, Sutton TT, Lancraft TM (1996) The trophic structure and predation impact of a low latitude midwater fish assemblage. Prog Oceanogr 38:205-239.

Hulley PA (1981) Results of the research cruises of FRV 'Walter Herwig' to South America. LVIII. Family Myctophidae (Osteichthyes, Myctophiformes). Arch FischWiss 31:1-300

Hutchinson GE (1959) Homage to Santa Rosalia or why are there so many kinds of animals? Am Nat 93:145-159

Hutchinson GE (1961) The paradox of the plankton. Am. Nat 95:137-145

Kawamura A, Fujii F (1988) Forage of the mesopelagic fishes, 
Symbolophorus californiensis (Eigenmann and Eigenmann) and Tarletonbeania taylori Mead caught in gill nets in the northwestern North Pacific Ocean. Bull Ocean Res Inst Univ Tokyo 26:143-159

Kinzer J, Schulz K (1985) Vertical distribution and feeding patterns of midwater fish in the central equatorial Atlantic. Mar Biol 85:313-322

Lancraft TM, Hopkins TL, Torres JJ (1988) Aspects of the ecology of the mesopelagic fish Gonostoma elongatum (Gonostomatidae, Stomiiformes) in the eastern Gulf of Mexico. Mar Ecol Prog Ser 49:27-40

MacArthur RH (1972) Geographical ecology. Harper and Row, New York

Maynard SD, Riggs FV, Walters JF (1975) Mesopelagic micronekton in Hawailan waters: faunal composition, standing stock, and diel vertical migration. Fish Bull US 73:726-736

Merrett NR, Roe HSJ (1974) Patterns and selectivity in the feeding of certain mesopelagic fishes. Mar Biol 28: $115-126$

Nishida S, Pearcy WG, Nemoto I (1988) Feeding habits of mesopelagic shrimps collected off Oregon. Bull Ocean Res Inst Univ Tokyo 26:99-108

Omori $M$ (1969) The biology of a sergestid shrimp Sergestes lucens Hansen. Bull Ocean Res Inst Univ Tokyo 4:1-83

Passarella KC, Hopkins TL (1991) Species composition and food habits of the micronektonic cephalopod assemblage in the eastern Gulf of Mexico. Bull Mar Sci 49:638-659

Pianka ER (1974) Niche overlap and diffuse competition. Proc Natl Acad Sci USA 71:2141-2145

Roe HSJ (1984) The diel migrations and distributions within a mesopelagic community in the northeast Atlantic. 2. Verti-

Editorial responsibility: Richard Haedrich (Contributing

Editor), St. John's, Newfoundland, Canada cal migrations and feeding of mysids and decapod Crustacea. Prog Oceanogr 13:269-318

Roe HSJ, Badcock $J$ (1984) The diel migrations and distributions within a mesopelagic community in the northeast Atlantic. 5. Vertical migrations and feeding of fish. Prog Oceanogr 13:389-424

Romesburg HC (1990) Cluster analysis for researchers. Robert E Krieger Publishing Company, Malabar, FL

Samyshev EZ, Shetinkin SV (1971) Myctophids: feeding patterns of some species of Myctophidae and Maurolicus muelleri caught in the sound dispersing layers in the northwestern African area. Ann Biol 28:212-215

Sutton TT, Hopkins TL (1996a) Trophic ecology of the stomiid (Pisces: Stomiidae) assemblage in the eastern Gulf of Mexico: strategies and impact of a mesopelagic top predator group. Mar Biol 127:179-192

Sutton TT, Hopkins TL (1996b) Species composition, abundance, and vertical distribution of the stomiid (Pisces: Stomiiformes) fish assemblage in the Gulf of Mexico. Bull Mar Sci 59(3):530-542

Walters JF (1976) Ecology of Hawaiian sergestid shrimps (Penaeidea: Sergestidae). Fish Bull US 74:799-836

Wiebe PH, Burt KH, Boyd SH, Morton AW (1976) A multiple opening/closing net and environmental sensing system for sampling zooplankton. J Mar Res 34:313-326

Willis JM, Pearcy WG (1980) Spatial and temporal variations in the population size structure of three lanternfishes (Myctophidae) off Oregon, USA. Mar Biol 57:181-191

Zaret TM, Rand AS (1971) Competition in tropical stream fishes: support for the competitive exclusion principal. Ecology 52:336-342

Submitted: December 15, 1996; Accepted: December 22, 1997 Proofs received from author(s): March 17, 1998 